\section{PhyllaNthus KoZHIKODIANUS SIVAR. \& MANI. (EUPHORBIACEAE) - A NEW RECORD FOR TAMIL NADU}

\section{P.S. Udayan ${ }^{1}$, K.V. Tushar ${ }^{1}$, Satheesh George ${ }^{1}$, A.K. Pradeep ${ }^{2}$ and Indira Balachandran ${ }^{1}$}

${ }^{1}$ Centre for Medicinal Plants Research (CMPR), Arya Vaidya Sala, Kottakkal Changuvetty, Kottakkal, Malappuram District, Kerala 676503 , India

${ }^{2}$ Department of Botany, Calicut University, Malappuram District, Kerala 673635, India

Email: ${ }^{1}$ avscmpr@sify.com; avscmpr@yahoo.co.in web supplement

Yercad, located in the Shevaroy hills of Salem district in Tamil $\mathrm{Nadu}$ is situated between $11^{\circ} 48^{\prime} \mathrm{N}$ and $78^{\circ} 11^{\prime} \mathrm{E}$ at an altitude of $1300 \mathrm{~m}$. While the rest of this region is generally dry, including the predominantly low and rocky hills of the Eastern Ghats, Yercad with its cool weather is a welcome contrast. The maximum temperature ranges between $25^{\circ} \mathrm{C}-30^{\circ} \mathrm{C}$ and minimum between $13{ }^{\circ} \mathrm{C}-16^{\circ} \mathrm{C}$. The average annual rainfall is around $1750 \mathrm{~mm}$. The soil is deep to very deep and non-calcareous. The topmost hill area is characterised by clay loam soil whereas the bottom of the valley is characterised by alluvial and clay loam soil. The forest types range from evergreen to moist deciduous. On the western side of the hills, fragments of sholas still exist, though a great portion of the plateau is cleared.

The present study conducted in 2004 in the Shevaroy hills of Yercad has resulted in the collection of 80 taxa of angiosperms. Of these, Phyllanthus kozhikodianus Sivar. \& Mani., is a new record for Tamil Nadu. It is briefly described here with phenological data, distribution, specimen examined and notes for better understanding of this taxon. The voucher specimens are deposited at the Centre for Medicinal Plants Research, Kottakkal.

\section{Phyllanthus kozhikodianus}

Sivar. \& Mani., Jour. Ind. Bot. Soc. 56: 165. 1977; Sivar. \& Joseph, J. Bombay Nat. Hist. Soc. 17: 369. 1981; Manilal \& Sivarajan, Fl. Calicut 264. 1982; Manilal et al., Fl. Silent Valley 254. 1988; Sasi. \& Sivar., Fl. Thrissur Forests 413. 1996; Nayar, Hot Spots End. Pl. India, Nepal \& Bhutan 212. 1996. Sivarajan \& Philip Mathew, Fl. Nilambur 639. 1997. (Euphorbiaceae)

Material examined: 10.vii.2004, 02887, Shevaroy Hills, Salem district, Tamil Nadu, $\pm 1330 \mathrm{~m}$, coll. Udayan et al. A good population of mature individuals was observed in the study area.

\section{Distribution: Kerala and eastern Himalaya.}

Description: Erect annual herbs, up to $60 \mathrm{~cm}$ tall. Leaves elliptic or obovate, glabrous, $2.5 \times 1.5 \mathrm{~cm}$, obtuse to subacute at apex, rounded at base; lateral nerves obscure; petioles ca. $1 \mathrm{~mm}$ long. Male flowers greenish-white, $2.5 \mathrm{~mm}$ across, in axillary fascicles of 2-3; tepals six, subequal; outer three ovate, acute at apex; inner three ovate, obtuse at apex; stamens three, filaments connate, anthers dehiscing transversely; disc glands six, star shaped. Female flowers green with prominent white margins, 3-4mm across, solitary, axillary; tepals six, same as male flowers, styles three, spreading. Capsules depressed globose, $3 \mathrm{~mm}$, glabrous, with accrescent long tepals. Seeds trigonous, vertically striate (Image $1^{\mathrm{w}}$ ).

Habitat: Common in moist deciduous to evergreen forests.

Phenology: Flowering and fruiting almost throughout the year.

Biotic association: It is common and found to grow near moist and shady localities of moist deciduous to evergreen forests. The associated species are Ageratum houstonianum Miller, Bidens pilosa L., Cotula australis (Spreng.) Hook.f., Crassocephalum crepidioides (Benth.) S. Moore, Emilia sonchifolia (L.) DC., Eupatorium glandulosum Kunth and Spilanthes calva DC. Murry, (Asteraceae); Cynoglossum zeylanicum (Vahl ex Hornem.) Thunb. ex Lehm. (Boraginaceae); Lobelia nicotianifolia Roth ex Schult. (Lobeliaceae); Physalis peruviana L., Solanum americanum Mill., Solanum giganteum Jacq. and Solanum viarum Dunal (Solanaceae); Polygonum chinense L. (Polygonaceae); Richardia scabra L. (Rubiaceae); Rubus ellipticus Smith (Rosaceae), Stephania japonica (Thunb.) Miers (Menisperamaceae) etc.

Remarks: This species was earlier reported from Calicut, (Silent Valley) Palakkad, Thrissur and Malappuram districts of Kerala state (Manilal \& Sivarajan, 1982; Manilal, 1988; Sasidharan \& Sivarajan, 1996; Sivarajan \& Mathew, 1997). The collection from Kuttikkanam, near Peermade of Idukki district extends its distribution further south in Kerala (20.v.2004, 02605, Kuttikkanam, Idukki district, Kerala, $+900 \mathrm{~m}$, Udayan et al.). So far none of the published floras of Tamil Nadu has reported this species. The present collection from Shevaroy Hills of Salem district is not only a new report to the state but also extends its distribution to the Eastern Ghats. It can be easily distinguished from the other herbaceous species of Phyllanthus in having more than $2 \times 1.5 \mathrm{~cm}$ leaf size, connate anthers and fruiting perianth lobes that are as long as the capsule (Manilal \& Sivarajan, 1982).

\section{REFERENCES}

Manilal, K.S. (1988). Flora of Silent Valley Tropical Rain Forests of India. Calicut University, Calicut.

Manilal, K.S. and V.V. Sivarajan (1982). Flora of Calicut. Bishen Singh Mahendra Pal Singh, Dehra Dun.

Sasidharan, N. and V.V. Sivarajan (1996). Flowering Plants of Thrissur forests (Western Ghats, Kerala, India). Scientific Publishers, Jodhpur.

Sivarajan, V.V. and P. Mathew (1997). Flora of Nilambur (Western Ghats, Kerala). Bishen Singh Mahendra Pal Singh, Dehra Dun.

\section{ACKnowledgement}

The authors are thankful to the authorities of Arya Vaidya Sala, Kottakkal and Department of Biotechnology, Government of India, for the financial support; greatly indebted to Dr. P.N. Ravindran, visiting scientist, for his constant encouragement and support. We express our gratitude to the authorities of Tamilnadu Forest Department and to Mr. U. Ravindran I.F.S., District Forest Officer, Salem for granting permission and arranging Mr. P. Balasubramanian, Forest Guard for the field visit. Thanks are also due to Mr. N.K. Janardhanan, Herbal Garden staff, for assisting us during the field visit.

${ }^{w}$ see Image 1 in the web supplement at www.zoosprint.org

(c) Zoo Outreach Organisation; www.zoosprint.org Manuscript 1271; Received 15 October 2004; Revised received 29 March 2005; Finally accepted 15 April 2005; Date of publication 21 May 2005 